\title{
FIRE: STRUCTURAL AND MATERIAL CONSEQUENCES
}

Balázs L. György ${ }^{1}$

Éva Lublóy ${ }^{2}$

UDK: 614.84:624.9

DOI:10.14415/konferencijaGFS2017.003

Summary: In addition to the mechanical properties, behaviourstructural materials at elevated temperatures is also of high importance. Present paper deals with the effects of fire attack on concrete or concrete structures in Hungary. Residual compressive strength of concrete exposed to high temperatures is influenced by the following factors: water to cement ratio, cement to aggregate ratio, type of aggregate, water content of concrete before exposing it to high temperatures and the fire process. Therefore, mix design and composition of concrete are of high importance.Material and structural behavior are analyzed at high temperatures, which, based on practical observations, could reach even $1100^{\circ} \mathrm{C}$ in some cases. Relationship of concrete mix design and structural behaviour arediscussed with test results on prestressed concrete beams. By the analysis of earlier fire attacks, important information can be obtained for future fire design.The fire cases of the Budapest Sports Hall (1999) and of the Athletic Hall of the University of Physical Education in Budapest, Hungary (2015) are also summarized in our paper.

Keywords:fire, deterioration, temperature dependent material properties, concrete, spalling

\section{INTRODUCTION}

Concrete has excellent properties at high temperatures compared to other structural materials. Concrete can also be used to protect other structural materials such as steel [1]. Effects of high temperatures on the mechanical properties of concrete have been studied as early as the 1940s[2]. In the 1960s and 1970s fire research was mainlydirected to study the behaviour of concrete structural elements [3].There was relatively little information on the concrete properties during and after fire [4].

The mechanical characteristics of the concrete are changing subjected to fire. During the cooling process concrete is not able to recover its original characteristics. Deterioration of concrete at high tempratures has two forms: (1) local damage in the material itself (Figure 1) and globaldamage resulting the failure of the elements (Figure 2).

${ }^{1}$ Professor, Head of Department, Budapest University of Technology and Economics, Department of Construction Materials and Technologies, H-1521 Budapest Hungary, balazs.gyorgy@epito.bme.hu ${ }^{2}$ Assistant professor, Budapest University of Technology and Economics, Department of Construction Materials and Technologies, H-1521 Budapest Hungary, lubloy.eva@epito.bme.hu 
Temperature influences are reflected in changes of physical and mechanical properties of concrete. Residual compressive strength of concrete exposed to high temperatures is influenced by the following factors [5]:

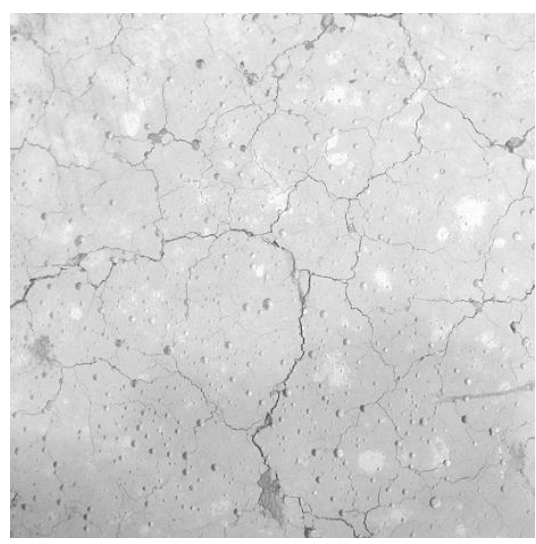

Figure 1. Damage of concrete

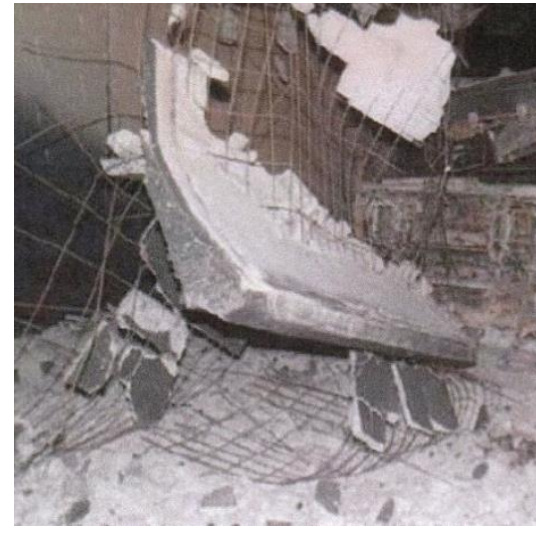

Figure 2. Damage of structure (http://www.polizia.ti.ch)

(1) water to cement ratio,

(2) cement to aggregate ratio,

(3) type of aggregate,

(4) type of cement,

(5) water content of concrete before exposing it to high temperatures and

(6) fire process.

Spalling of concrete cover may have two main reasons: (1) internal vapour pressure (mainly for conventional concretes) and (2) overloading of concrete compressed zones (mainly for high strength concretes).

\section{OUR EXPERIMENTAL STUDIES}

Purpose of our experimental study was to improve fire resistance of a typical thin webbed prestressed pretensioned concrete roof girder. Owing the small thickness of the web (Fig. 4 ), special considerations were needed to modify the composition of concrete mix. The reference concrete grade was $\mathrm{C} 50 / 60$.

\section{1 Testing of material properties}

Preliminary fire tests indicated inadequate fire resistance of a typical thin webbed $(60 \mathrm{~mm}$, thickness), prestressed pretensioned roof girder. The self-compacting concrete (SCC) mix included limestone as filling material. Cement type was CEM I 42.5 N. This composition and the very low thickness of web resulted early spalling of concrete cover. 
Contemporary achievements in civil engineering 21. April 2017. Subotica, SERBIA

In order to be able to improve fire resistance of the concrete mix as well as that of the girder, our intension was directed to optimize the concrete mix without changing the geometry of thegirder. Therefore, we decided to modify the concrete composition:

1. changing the filling material from limestone to slag in addition to (Table 1)

2. adding polypropylene fibres to the mix $\left(1 \mathrm{~kg} / \mathrm{m}^{3}\right.$ or $2 \mathrm{~kg} / \mathrm{m}^{3}$, (Table 1$)$.

Table 1. Test parameters (all other parameters were the same for the mixes)

\begin{tabular}{|l|l|l|c|c|}
\hline $\begin{array}{l}\text { Concrete } \\
\text { mix }\end{array}$ & filling material & PPfibres & $\begin{array}{l}\text { material test } \\
20^{\circ} \mathrm{C}, 600^{\circ} \mathrm{C}, \\
800^{\circ} \mathrm{C}\end{array}$ & $\begin{array}{l}\text { beam } \\
\text { test }\end{array}$ \\
\hline $\begin{array}{l}\text { Mix 1 } \\
\text { (reference) }\end{array}$ & limestone & $0 \mathrm{~kg} / \mathrm{m}^{3}$ & + & + \\
\hline Mix 2 & limestone & $1 \mathrm{~kg} / \mathrm{m}^{3}$ & + & - \\
\hline Mix 3 & limestone & $2 \mathrm{~kg} / \mathrm{m}^{3}$ & + & + \\
\hline Mix 4 & slag & $1 \mathrm{~kg} / \mathrm{m}^{3}$ & + & + \\
\hline
\end{tabular}

Material tests were carried out on cube specimens of $150 \mathrm{~mm}$ sides kept 2 hours on $600{ }^{\circ} \mathrm{C}$ or $800^{\circ} \mathrm{C}$ then cooled down to room temperature. Material tests were carried out at the Department of Constructions Materials and Technologies, Budapest University of Technology and Economics. In case of our reference mix (Mix 1) a special type of failure occurred during the heating process within the temperature range of 600 to $800^{\circ} \mathrm{C}$. Some corners of the cube specimens cracked off. This phenomenon could be explained by the stress concentrations in corner regions due to the high temperatures. Stress concentrations in the corners may indicate deterioration of structural performance of an element or possible spalling of concrete cover. By addition of $1 \mathrm{~kg} / \mathrm{m}^{3}$ polypropylene fibres, failure of the specimen (corner cracking) did not occur, however, surface cracking was observed.By further increase of fibre content $2 \mathrm{~kg} / \mathrm{m}^{3}$ PP fibres instead of $\mathrm{kg} / \mathrm{m}^{3}$, the relative residual compressive strength decreased by about $8 \%$. We have observed the highest relative residual compressive strength by changing the filling material from limestone to slag and including also $1 \mathrm{~kg} / \mathrm{m}^{3}$ polypropylenefibres subjected to $800^{\circ} \mathrm{C}$ (Figure 3).

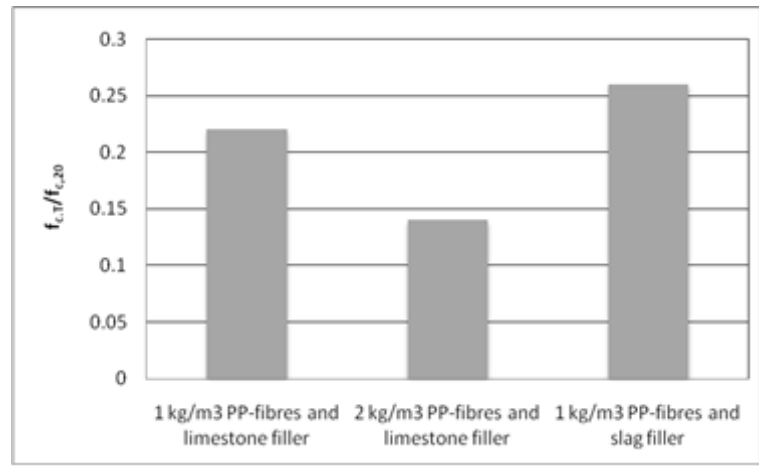

Figure 3.Measured relative, residual compressive strength values for tested concrete mixes with $800^{\circ} \mathrm{C}$ (every point is an average of 3 measurements, relative values are related to those at $20^{\circ} \mathrm{C}$ ) 


\section{2 Tests with beam elements}

Fire tests on beam specimens were carried out with mixes 1, 3 and 4 (see Table 1), in Fire Laboratory of ÉMI Nonprofit Ltd. The heating curve for the furnace was the following:

where

$$
\mathrm{T}=345 \log _{10}(8 \mathrm{t}+1)+20
$$

$\mathrm{T}$ is the average furnace temperature $\left({ }^{\circ} \mathrm{C}\right)$

$\mathrm{t}$ is the time (min).

The temperature increase was controlled by thermocouples during the heating process.

a)

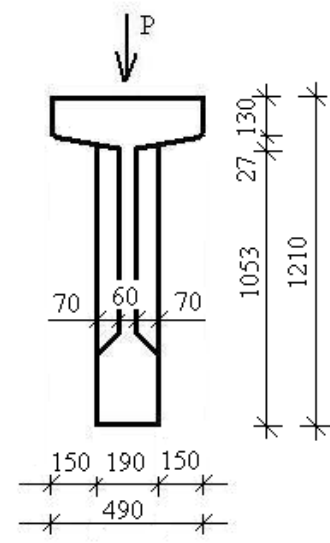

b)

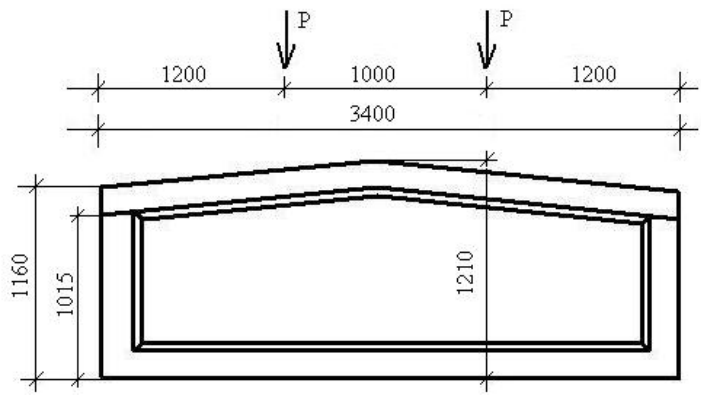

Figure 4.Tested beam specimens [6]

The length of beams was $3.4 \mathrm{~m}$. The prestressing force was $130 \mathrm{kN}$. First, the beam was loaded with $\mathrm{P}=2 \times 350 \mathrm{kN}$ during the fire test (Figure 4). Test beam with reference mix (Mix 1) failed in 12 minutes owing to the complete spalling of concrete cover of the web (Fiure5).Test beam with Mix 2 including $1 \mathrm{~kg} / \mathrm{m}^{3}$ polypropylene fibres failed in 42 minutes in shear (without spalling of concrete cover). Test beam with Mix 4 including 1 $\mathrm{kg} / \mathrm{m}^{3}$ polypropylene fibres and slag as filling material instead of lime stone failed in 67 minutes in shear (without spalling of concrete cover).

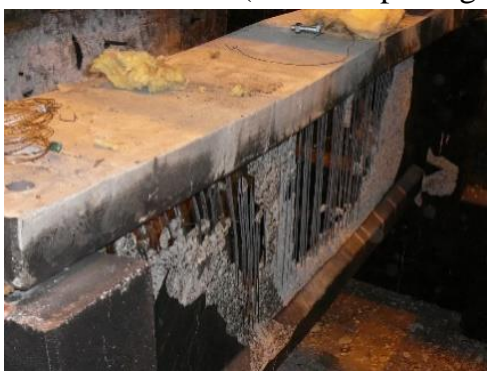

Figure 5.Beam with the reference

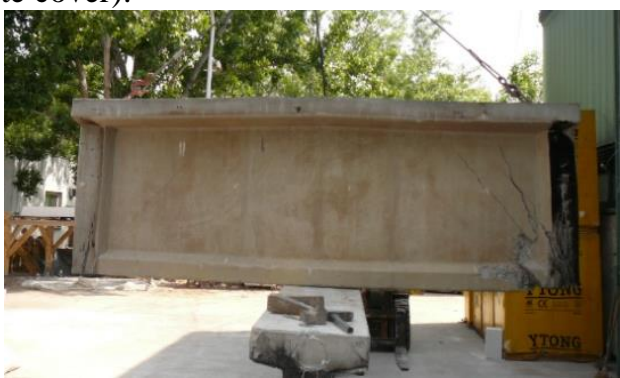

Figure 6.Beam with Mix 4 after failure concrete (Mix 1) after failure2010, Szentendre, Hungary [7] 
Contemporary achievements in civil engineering 21. April 2017. Subotica, SERBIA

\section{RECENTLARGE FIRE CASES IN BUDAPEST}

The Budapest Sports Hall in Budapest, Hungary was designed in the period from 1974 to 1978. The diameter and the height of the double-walled cylindrical hall were 120 and 26 meters, respectively. In the rectangular jetty attached to the main building, the training halls were located [8]. For the roofing of the Sports Hall a cable covering technique was used that was developed and tested in the Soviet Union. The hall's structural system was mainly composed of two parts: at firs the circularly positioned rows of pillars bearing the purely steel structure cable suspension roof and the steelwork supporting the upper floors of the ring-shaped building, secondly the reinforced concrete structure grandstand encircling the arena, as well as the connected 1st and 2nd floor ceiling-elements. In general, the bearing structural elements of the building were made of reinforced concrete. The Budapest Sports Hall became a favourite venue of business seminars, and general meetings of banks and share companies [9]. Not only the inflammable materials were destroyed or damaged by the fire of 15 December 1999, but the bearing structure suffered also permanent deformations and structural damage in the materials, therefore, the demolishion of the Sports Hall was decided [10].

The intensity of the fire can be judged from its long duration ( 3 hours), and from the extent of the damage of different structures. Based on the damages caused by this particular fire case, the general conclusion may be drawn that large part of the structure were exposed to high temperature $\left(800-900{ }^{\circ} \mathrm{C}\right.$, or incidentally even higher) for long duration [11].

No considerable damage could be observed by visual observation of the load bearing structure. At some parts signs of dislocation and inside tension could be ascertained. The concrete fittings at the ends of the beams weighing on pillars partly broke off.

Fire damages in the ground level were so severe especially in the area close to the arena -that such deformations could be noticed which locally endangered the stability of the building's bearing structures. The bounding reinforced concrete masonry of the arena was severely damaged by the fire, and a considerable part of its surface became cracked and broken. At some parts the reinforced concrete beams and U-panels were broken and cracked, where the concrete was pink-coloured. $70-80 \%$ of the floor structure was also considerably cracked and broken.

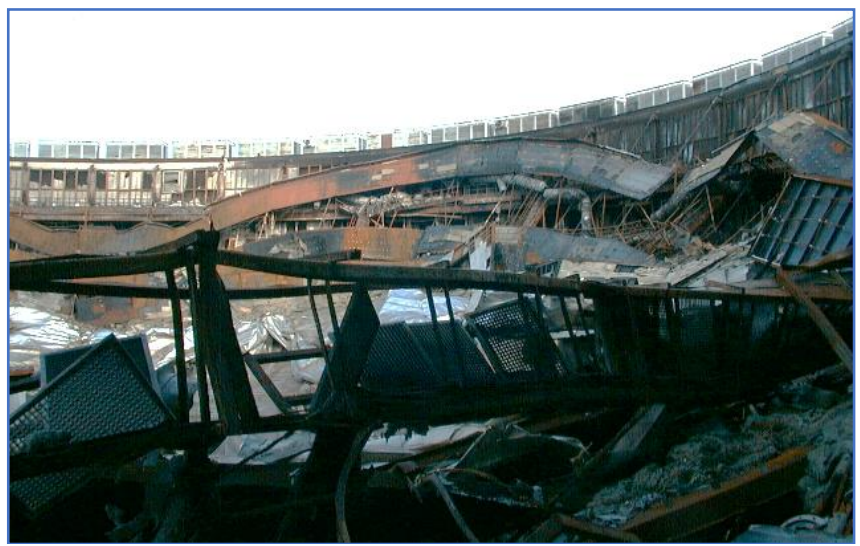

Figure 7. The deformed steel rings, Budapest Sports Hall, Dec. 1999[10] 
There were cracks on the concrete structures of the 1st and 2nd floors, however these did not influence considerably the bearing capacity and stability of the structure. On the 1st floor $25 \%$, while on the 2nd floor $10-15 \%$ of the bearing structures deteriorated in such an extent that measures had to be taken. The most considerable strength and structural damages were observed in the materials of the area of the cloakroom on the 1st floor, where, all concrete structures suffered strong or medium damages. The damages of the pillars were not significant, however the displacements and cracks implied structural movements. On the basis of inspection it could be said that the 2nd floor suffered lower fire attack; here, damages of smaller extent of probably local character occurred. The bearing structures suffered the most severe damages on the 3 rd floor. The steel structures suffered considerable deformations (Figure 7) during the fire.

The 4th floor of the ring-shaped building was mainly exposed to underneath thermal load; therefore, the floor structure of the ceiling, which confined this level from beneath suffered major damage.

At about 5 o' clock early morning 15 October 2015 the Athletic Hall of the University of Physical Education in Budapest, Hungary caught fire. The fire - in the nearly $3000 \mathrm{~m} 2$ hall - could only be extinguished at the early afternoon. The steel truss roof system completely collapsed. The hall became unusable. Our first experiences about the behaviour of steel and concrete elements subjected to fire are summarised below.

At some locations the temperature of the reinforced concrete was higher than $500{ }^{\circ} \mathrm{C}[12]$. Explosive spalling of the concrete cover was observed on the pillars and the beams (Figure 8.a). Stability failure of precast concrete wall elements and slab elements occurred, due to the failure of the steel elements (Figure 8.b).

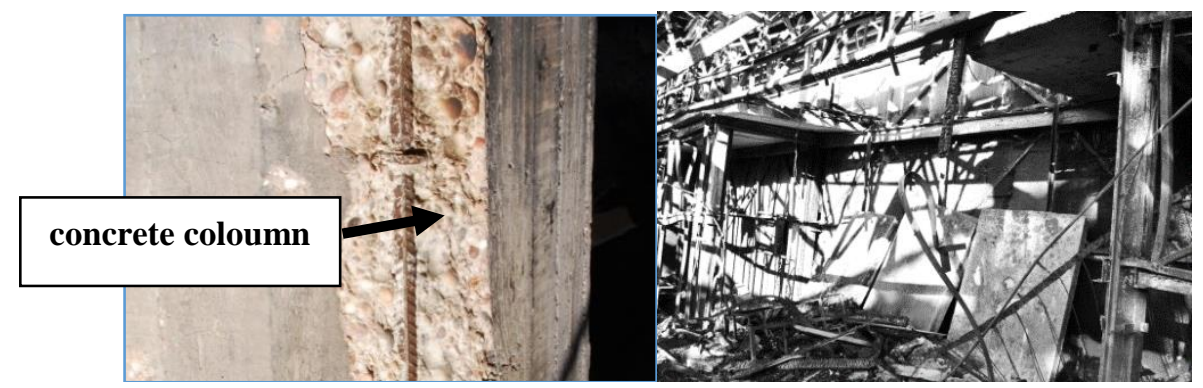

Figure 8.. a) Explosive spalling of the concrete cover, b) stability failure of concrete slab Univ. of Physical EducationOct. 2015, Budapest, Hungary [12]

\section{SUMMARY AND CONCLUSIONS}

Concrete is a composite material, that consists mainly of mineral aggregates bound by a matrix of hydrated cement paste, and may suffer in fire. The matrix is highly porous and contains a relatively large amount of free water unless artificially dried. When exposed it to high temperatures, concrete undergoes changes in its chemical composition, physical structure and water content. These changes occur primarily in the hardened cement paste in unsealed conditions. Such changes are reflected by changes in the physical and 
Contemporary achievements in civil engineering 21. April 2017. Subotica, SERBIA

mechanical properties of concrete that are associated with temperature increase. Deterioration of material characteristics and structural performance highly depend on constituents and on the temperature history. In order to understand the complex phenomenon due to high temperatures in concrete an extensive study was carried out including filling materials, polypropylene fibers. Our studies were resulted to both material tests, beam tests and structures subjected to high temperatures.

\section{Results of material tests}

In case of our starting mix (reference mix, Mix 1) cube specimens failed during the heating process within the temperature range of 600 to $800^{\circ} \mathrm{C}$. By addition of $1 \mathrm{~kg} / \mathrm{m}^{3}$ polypropylene fibres, failure of the specimen (corner cracking) did not occur, however, surface cracking was still observed.The highest relative residual compressive strength as well as the minimum amount of surface cracking were observedby changing the filling material from limestone to slag and including also $1 \mathrm{~kg} / \mathrm{m}^{3}$ polypropylenefibres subjected to $800^{\circ} \mathrm{C}$.

\section{Results of beam tests}

Test beam with reference mix (Mix 1) failed in 12 minutes owing to the complete spalling of concrete cover of the web. Test beam with Mix 2 including $1 \mathrm{~kg} / \mathrm{m}^{3}$ polypropylene fibres failed in 42 minutes in shear (without spalling of concrete cover). Test beam with Mix 4 including $1 \mathrm{~kg} / \mathrm{m}^{3}$ polypropylene fibres and slag as filling material failed in 70 minutes in shear (without spalling of concrete cover).

\section{Structural behaviour}

In case of the Budapest Sports Hall: there were cracks on the concrete structures of the 1st and 2 nd floors, however these did not influence considerably the load bearing capacity and stability of the structure. On the 1 st floor $25 \%$, while on the 2nd floor $10-15 \%$ of the load bearing structures deteriorated in such an extent that measures had to be taken. The most severe strength and structural damages were observed in the materials at the area of the cloakroom on the 1 st floor.

In case of slab-interjoists systems: the slabs were damaged due to the fire. Some of the pretensioned E-girders were cracked. The concrete became red-coloured, indicating that the maximum temperature was around $500{ }^{\circ} \mathrm{C}$. The bottom parts of the concrete and the brick interjoists fall down.

In case of the Athletic Hall of the University of Physical Education in Budapest: explosive spalling of the concrete cover was observed on the pillars and the beams and stability failure of precast concrete wall elements and slab elements was caused by the failure of the steel elements.

\section{ACKNOWLEDGEMENTS}

Authors acknowledge the support by the Hungarian Research Grant NVKP_16-1-20160019 "Development of concrete products with improved resistance to chemicalcorrosion, fire or freeze-thaw". 


\section{REFERENCES}

[1] Khoury, G. A., Grainger, B. N., Sullivan, P. J. E. Transient thermal strain of concrete: literature review, conditions within specimen and behaviour of individual constituents, Magazine of Concrete Research, Vol. 37, No. 132, 1985 pp. 37-48.

[2] Schneider, U. (1988): "Concrete at high temperatures-a general review", Fire Safety Journal, Vol 13, 1988, pp. 55-68

[3] Kordina, K. (1997): „Fire resistance of reinforced concrete beams“ (Über das Brandverhalten punktgeschützter Stahbetonbalken), Deutscher Ausschuss für Stahlbeton, Heft 479, ISSN 0171-7197, Beuth Verlag GmbH, Berlin, 1997.

[4] Waubke, N. V. Physical analysis of strength reduction of concrete up to $1000{ }^{\circ} \mathrm{C}$ (Über einen physikalischen Gesichtspunkt der Festigkeitsverluste von Portlandzement-betonen bei Temperaturen bis $1000{ }^{\circ} \mathrm{C}$-Brandverhalten von Bauteilen), Dissertation, TU Braunschweig, 1973.

[5] Thielen, K. Ch. Strength and Deformation of Concrete Subjected to high Temperature and Biaxial Stress-Test and Modelling (Festigkeit und Verformung von Beton bei hoher Temperatur und biaxialer Beanspruchung - Versuche und Modellbildung), Deutscher Ausschuss für Stahlbeton, Heft 437 Beuth Verlag GmbH, Berlin, 1994.

[6] Lublóy E. and Balázs G.L.Modifications of material properties due to elevated temperatures.Advances in Construction Materials, 23-27 July 2007, ISBN 978-3-54072447-6, (Ed. Grosse Ch. U.), Springer, 2007.

[7] Balázs G. L., Lublóy Ė. and Mezei S. Potentials in concrete mix design to improve fire resistance.Concrete Structures Journal,2010,Vol. 11, pp.: 19-24.

[8] Enyedi, L.: Our new sports establishment: The Budapest Great Hall, Almanac of the review "Life and sience" (In Hungarian: Új Sportlétesítményünk: a Budapesti Nagy Csarnok, Élet és Tudomány Kalendáriuma), 1980.

[9] Bátor ,T.: The Budapest Sports Hall Budapest, The National Stadion and its institution Sportcsarnok, Népstadion és Intézményei, 1994.

[10]ÉMI.: Expertise on the fire-damaged structures of the Budapest Sports Hall (In Hungarian: Szakértői vélemény a Budapest Sportcsarnok tüzkárt szenvedett épületszerkezeteiröl), 2000.

[11] Majoros É., Balázs G. L.: Degree of deterioration due to fire in large concrete halls, Periodica polytechnika-civil engineering, 2004, Vol. 48 Nr.1-2 pp. 141-156tf.hu (2011): http://tf.hu/hirek/9529/diplomaoszto-2/ (downloaded: 2015. 12. 08.)

[12] Lublóy É., Czoboly O., Hlavička V., Oros Zs., Balázs L. Gy. Experiences of the fire case of athletic hall of the University of Physical Education in Budapest 15 Oct. 2015 (In Hungarian: Testnevelési Egyetem atlétikai csarnok Budapest, tüzeset 2015. október 15. - következmények), Vasbetonépités, 2015, ISSN 1419-6441, online ISSN: 1586-0361, Vol.17, No. 3, pp. 50-55. 